\title{
The Effect of Threads Geometry on Insertion Torque (IT) and Periotest Implant Primary Stability: A High-Density Polyurethane Simulation for the Anterior Mandible
}

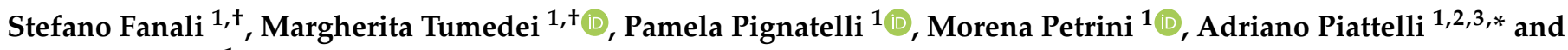 \\ Giovanna Iezzi ${ }^{1}$ \\ 1 Department of Medical, Oral and Biotechnological Sciences, University "G. D'Annunzio" of Chieti-Pescara, \\ Via dei Vestini 31, 66100 Chieti, Italy; fanali@odontoiatra.com (S.F.); margytumedei@yahoo.it (M.T.); \\ pamelapignatelli89p@gmail.com (P.P.); petrini.morena@gmail.com (M.P.); gio.iezzi@unich.it (G.I.) \\ 2 Cátedra Internacional de Investigación en Odontología, Catholic University of San Antonio de \\ Murcia (UCAM), Av. de los Jerónimos, 135, Guadalupe, 30107 Murcia, Spain \\ 3 Fondazione Villa Serena per la Ricerca, Via Leonardo Petruzzi 42, 65013 Città Sant'Angelo (PE), Italy \\ * Correspondence: apiattelli@unich.it \\ $+\quad$ These two authors contributed in equal parts to this study.
}

check for

updates

Citation: Fanali, S.; Tumedei, M.; Pignatelli, P.; Petrini, M.; Piattelli, A.; Iezzi, G. The Effect of Threads Geometry on Insertion Torque (IT) and Periotest Implant Primary Stability: A High-Density Polyurethane Simulation for the Anterior Mandible. Crystals 2021, 11, 308. https://doi.org/10.3390/cryst 11030308

Academic Editor: Laurent Tapie

Received: 28 February 2021

Accepted: 19 March 2021

Published: 20 March 2021

Publisher's Note: MDPI stays neutral with regard to jurisdictional claims in published maps and institutional affiliations.

Copyright: (c) 2021 by the authors. Licensee MDPI, Basel, Switzerland. This article is an open access article distributed under the terms and conditions of the Creative Commons Attribution (CC BY) license (https:/ / creativecommons.org/licenses/by/ $4.0 /)$.

\begin{abstract}
The implant geometry provides a key role in the osseointegration process and is able to improve the mechanical interaction and primary stability into the bone tissue. The aim of the present investigation was to compare different implant profiles to evaluate their influence on the primary stability on high-density polyurethane block. Methods: A total of 100 implants were used on 20 pcf polyurethane density in the present investigation, i.e., 20 implants for each of 5 groups (A, B, C, D, and E), characterized by different thread pitch and geometry. The insertion torque (IT), and Periotest mean values were recorded during the implant positioning. Results: Mean values for insertion torque values were higher for the group $\mathrm{C}$ and group $\mathrm{E}$ implant profiles when compared to all other groups $(p<0.01)$. No significant differences were detected between these two groups $(p<0.05)$. Lower IT $\left(<20 \mathrm{Ncm}^{2}\right)$ were presented by groups A, B, and D $(p<0.05)$. All groups showed negative Periotest values. Group $C$ implants showed the lowest level of Periotest values $(p<0.05)$. No significant Periotest differences were found between group B and group D and between group A and group $\mathrm{E}(p>0.05)$. Conclusions: Implants with a wider and V-thread profile and a round apex showed a higher stability in a standardized polyurethane foam. Their use could be suggested in high-density bone in clinical practice.
\end{abstract}

Keywords: insertion torque; Periotest; polyurethane block; primary stability; thread geometry; thread pitch

\section{Introduction}

The osseointegration of dental implants represents a multifaceted process that produces an intimate interface between the implant and the bone tissue without interposition of fibrous soft tissue [1-3]. The defect generated during the implant site drilling is able to produce a healing process similar to a primary fracture [4-6]. The dental implant healing process could be categorized in two different phases known as primary stability and secondary stability. The primary stability is determined by the mechanical contact and retention with the cortical bone around the implant. This intimate relationship between the interfaces plays a fundamental importance because an insufficient primary stability could generate an early failure of the implant, and the persistence of micromovements over 150 microns could determine the formation of connective, fibrous tissue at the interface [7-10]. The secondary stability is followed by a sequelae of physiological events that produce a woven bone formation, adaptation, and remodeling of the structures under 
masticatory loading [11-16]. Some of the most important factors for primary stability are determined by:

(1) the bone density around the implant [17-19], that is determined by the medullary/ cortical bone ratio of the jaw's local anatomy [20,21];

(2) the quantity of bone-to-implant interface generated during the implant positioning that could be influenced by several factors such as the surgical preparation technique (standard drilling protocol [22,23], osteocondensation [24,25], and piezoelectric device procedure [26-28]);

(3) the macro and micro geometry of the implant screw.

Periotest and insertion torque (IT) are noninvasive, quantitative, and reproducible methods clinically used for determining primary stability. Periotest could also be used to evaluate the degree of osseointegration during the healing period, and in the long-term follow-up of the implant $[29,30]$.

The polyurethane study model represents a highly-standardized method to simulate the relationship between metal implants and bone [31-39]. The polyurethane model has been proposed to simulate the medical and implants devices on an artificial substrate with a microstructure, density, and physical and mechanical characteristics similar to the human bone $[36,37,40]$. Moreover, the polyurethane is chemically and thermally stable in wide environmental conditions, homogeneous and resistant to the desiccation which makes it optimal for in vitro testing $[36,37,40]$. The aim of the present study was to investigate the impact of five cylindrical-shaped implants, with different thread pitch, width, and depth, on primary stability in polyurethane bone models. The hypothesis that different insertion torque values and different Periotest measurements could be found between the different implant designs was tested.

\section{Materials and Methods}

\subsection{Polyurethane Foam Blocks}

Cellular rigid polyurethane blocks (models 1522-12; Sawbones; Pacific Research Laboratories Inc., Vashon, WA, USA) were used for the present study. The bone model has larger pores to mimic maxillary cancellous bone with cell size ranges from 0.5 to $2.0 \mathrm{~mm}$ diameter for this primarily closed cell foam. The density of the block resembled D2 bone type of the Lekholm classification, with a thick layer of cortical bone surrounding a core of dense trabecular bone, and was $0.32 \mathrm{~g} / \mathrm{cm}^{3}$ (20 PCF) with an elastic modulus of $137 \mathrm{MPa}$ and compressive strength of $5.4 \mathrm{MPa}$ [41]. The cortical bone was simulated by short e-glass fibers filler in a structure model.

In total three bone blocks were used for this study, and the dimensions of each experimental specimen were $13 \mathrm{~cm} \times 18 \mathrm{~cm} \times 4 \mathrm{~cm}$.

\subsection{Implants Characteristics}

Specifically, 100 cylindrical-shaped implants were used $(3.8 \mathrm{~mm} \times 12 \mathrm{~mm}$; FMD, Rome, Italy): group A (Figure 1), 20 Elisir cylindrical implants, with neck of $\varnothing 3.5 \mathrm{~mm}$; group B (Figure 2), 20 Elisir long-thread cylindrical implants with neck of $\varnothing 3.5 \mathrm{~mm}$; group $C$ (Figure 3), 20 Shiner cylindrical implants with a large neck of $\varnothing 4.8 \mathrm{~mm}$ in diameter; group D (Figure 4), 20 Storm cylindrical implants with neck of $\varnothing 4.1 \mathrm{~mm}$ and an external hexagon connection; Group E (Figure 5), 20 Crystal one-stage implants, large thread. All implant surfaces were sandblasted with large grit and acid etching. 

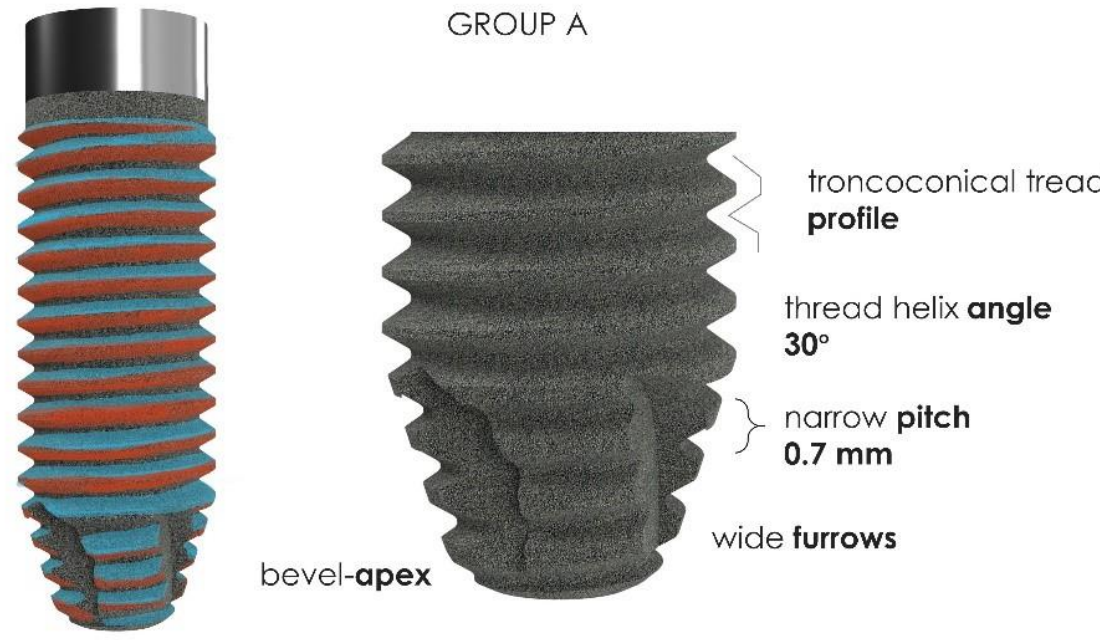

Figure 1. Group A: in detail, the morphology and thread geometry of the cylindrical implants.

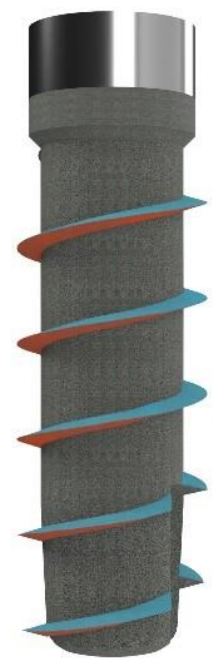

GROUP B

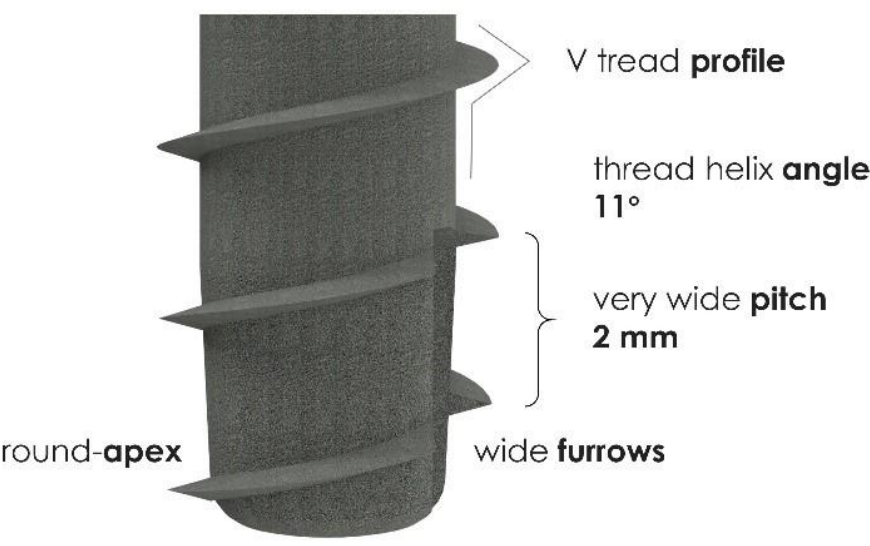

Figure 2. Group B: in detail, the morphology and long-thread geometry of the cylindrical implants.

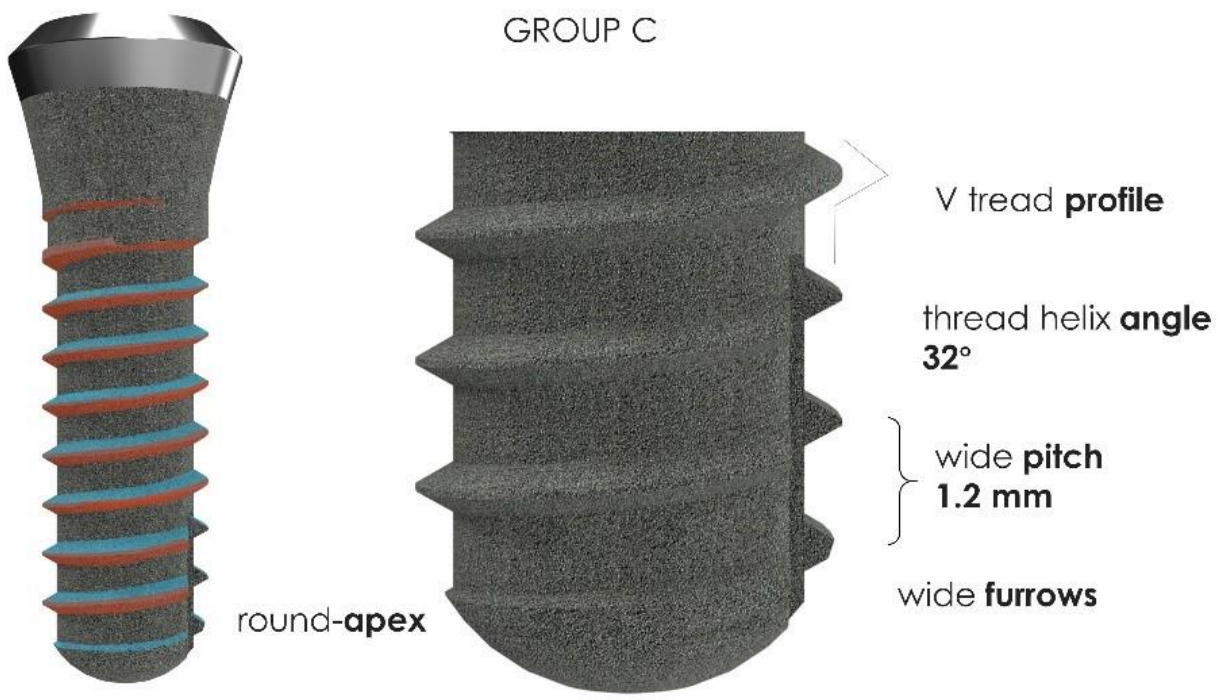

Figure 3. Group C: in detail, the morphology and thread geometry of the cylindrical implants. 


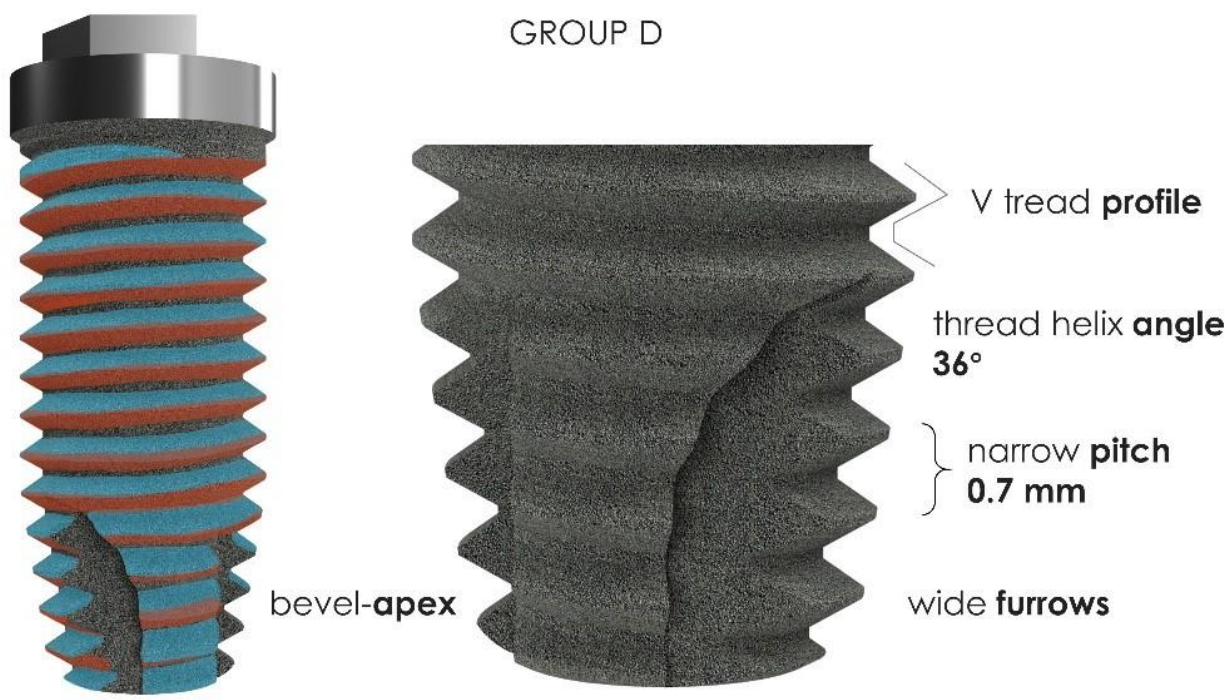

Figure 4. Group D: in detail, the morphology and thread geometry of the external hexagon cylindrical implants.
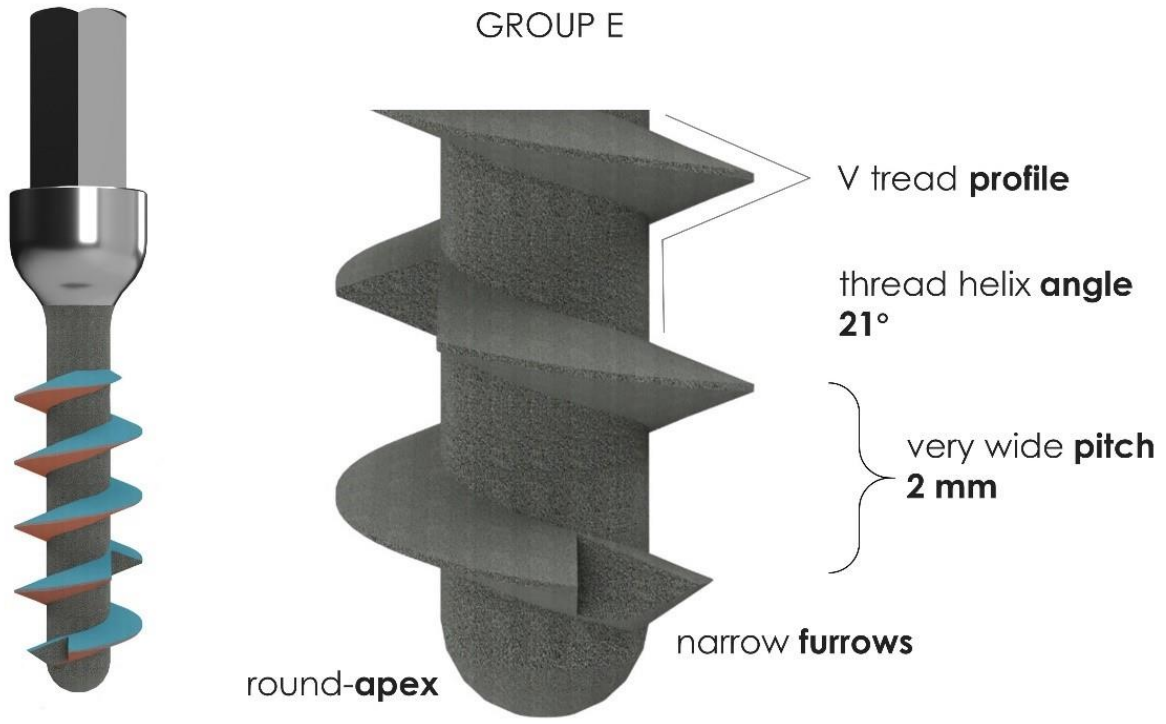

Figure 5. Group E: in detail, the morphology and thread geometry of the one-stage screw implants.

\subsection{Preparation of Implant Insertion Site}

The polyurethane bone blocks were fixed with a fastener (Figure 6). Osteotomy was prepared at a $4 \mathrm{~cm}$ distance between implants, with a gentle surgical technique using a surgical drill at a rotational speed of $800 \mathrm{rpm}$. A total of 100 drilling sites were performed into the polyurethane blocks. The drilling was performed according to the manufacturer's instructions. The succession of drills was: pilot drill, three intermediate drills $(\varnothing 2.3 \mathrm{~mm}$, $\varnothing 2.5 \mathrm{~mm}$, and $\varnothing 2.8 \mathrm{~mm}$ in diameter), and final drill (Ø $3.2 \mathrm{~mm}$ in diameter) for groups $\mathrm{A}$, $B$ and C, drill diameters $\varnothing 2.3 \mathrm{~mm}$ and $\varnothing 2.8 \mathrm{~mm}$ for group $\mathrm{D}$, and $\varnothing 2 \mathrm{~mm}$ and $\varnothing 2.3 \mathrm{~mm}$ for group E. All implants were placed according to the manufacturers' standard protocol and the minimum distance between implants was at least $3 \mathrm{~mm}$ according to the literature. After implant placement, implant primary stability was measured by means of insertion torque (ITv) and Periotest values (PTV). 


\section{Study design}

\section{Implants- 5 Groups}

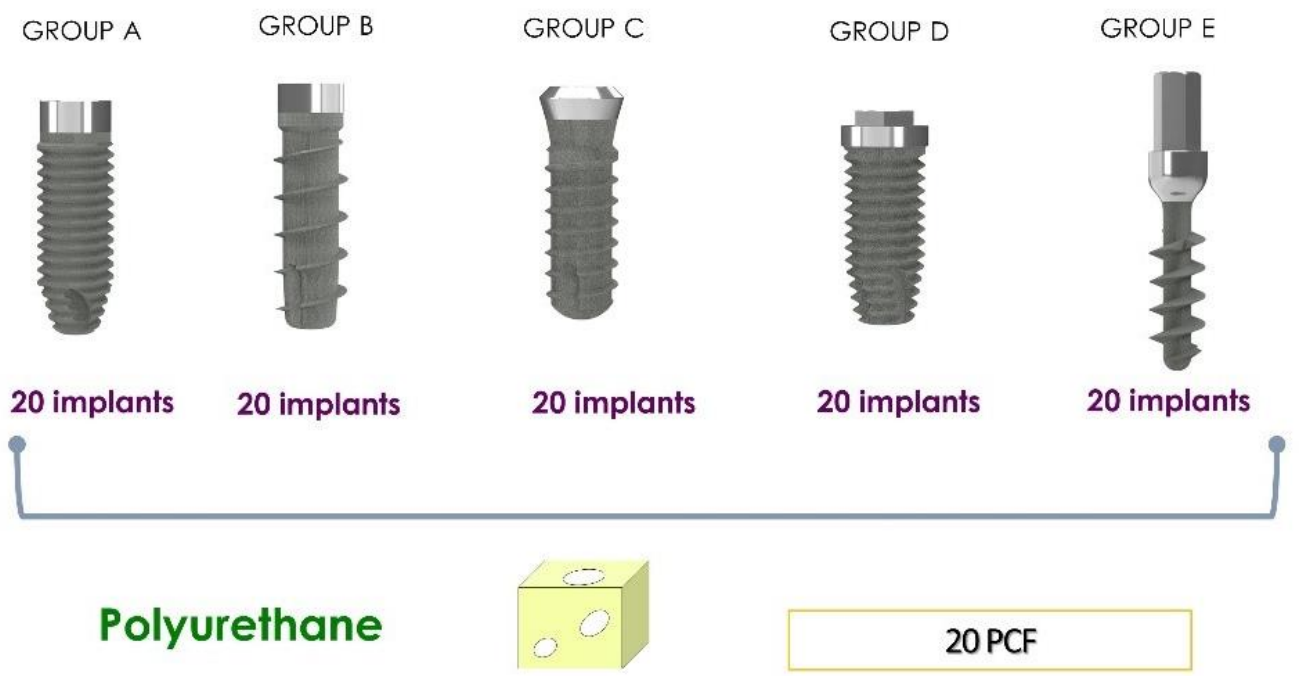

Figure 6. A graphical representation of the study design model.

\subsection{Measurement of Insertion Torque}

When inserting the implant, the peak insertion torque values were measured to the final $1 \mathrm{~mm}$ with a digital torque gauge instrument (Torque Meter PCE-TM 80; PCE Instruments, PCE Holding $\mathrm{GmbH}$, Meschede, Germany) with a measurement range of $0-147$ Ncm (Figure 7).

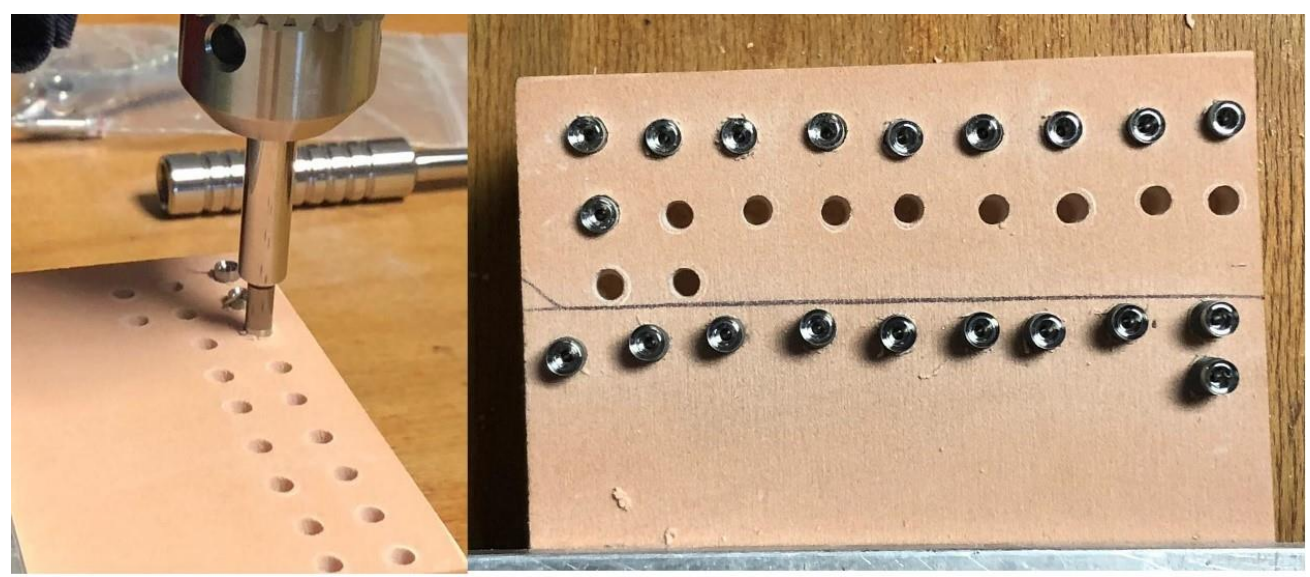

Figure 7. In detail, the phases of implant positioning into the polyurethane block.

\subsection{Periotest Analysis}

Periotest (Siemens, Bensheim, Germany), an electronically controlled rod weighting $8 \mathrm{~g}$, tapped each implant 4 times $/ \mathrm{s}$ for $4 \mathrm{~s}$ at a constant speed of $0.2 \mathrm{~m} / \mathrm{s}$. The rod decelerated when it touched the implant. The values ranged from -8 to +50 (PTV) by measuring the deceleration of the tapping instrument. The ranges of PTV reportedly have different meaning: -8 to 0 , good osseointegration; $1-9$, a borderline implant requiring clinical examination; and $\geq 10$, insufficient osseointegration.

The handpiece sleeve was set at a fixed distance from a flat surface of the hexagon and centered perpendicularly to the long axis of the implant. Three measurements were 
recorded for each sample in 4 directions. For the statistical consideration, the mean value of the Periotest measurement for each implant was considered in order to reduce the bias associated to the viscoelastic properties of polyurethane block polymers and the resilience forces settling around the fixture positioned.

The Periotest measurements were performed through a dedicated abutment adapted in the chamber of the implant. The measurement of the one-stage implants (group E) was performed directly on the transmucosal portion of the fixture.

\subsection{Statistical Analysis}

The insertion torque and Periotest micromovement values were statistically evaluated. The normality was evaluated by Shapiro-Wilk test, and the one-way ANOVA followed the Sidak multiple comparisons test for heterogeneous variances. The data were analyzed by the software package GraphPad 6.0 statistical package (Prism San Diego, CA, USA). The level of significance was set at $p<0.05$.

\section{Results}

Mean values for insertion torque measurements are presented in Table 1 and Figure 8. The IT means were higher for the groups $C$ and $E$ when compared to all other groups $(p<0.01)$ (Table 2). No significant difference was detected between these two groups $(p<0.05)$. Lower IT values $\left(<20 \mathrm{Ncm}^{2}\right)$ were evidenced for groups A, B, and D $(p<0.05)$. The Periotest analysis is reported in Tables 3 and 4 and Figure 8. All groups showed negative Periotest values. Group C implants showed the lowest Periotest values $(p<0.05)$. No significant Periotest differences were present between groups $\mathrm{B}$ and $\mathrm{D}$ and between groups $\mathrm{A}$ and $\mathrm{E}(p>0.05)$.

Table 1. Insertion torque means of the study groups.

\begin{tabular}{ccc}
\hline Insertion Torque $\left(\mathbf{N c m}^{2}\right)$ & Mean & SD \\
\hline GROUP A & 17.75 & 3.354 \\
\hline GROUP B & 15.15 & 5.383 \\
\hline GROUP C & 27.95 & 5.68 \\
\hline GROUP D & 15.7 & 3.42 \\
\hline GROUP E & 32.3 & 8.298 \\
\hline
\end{tabular}

INSERTION TORQUE

\section{PERIOTEST}
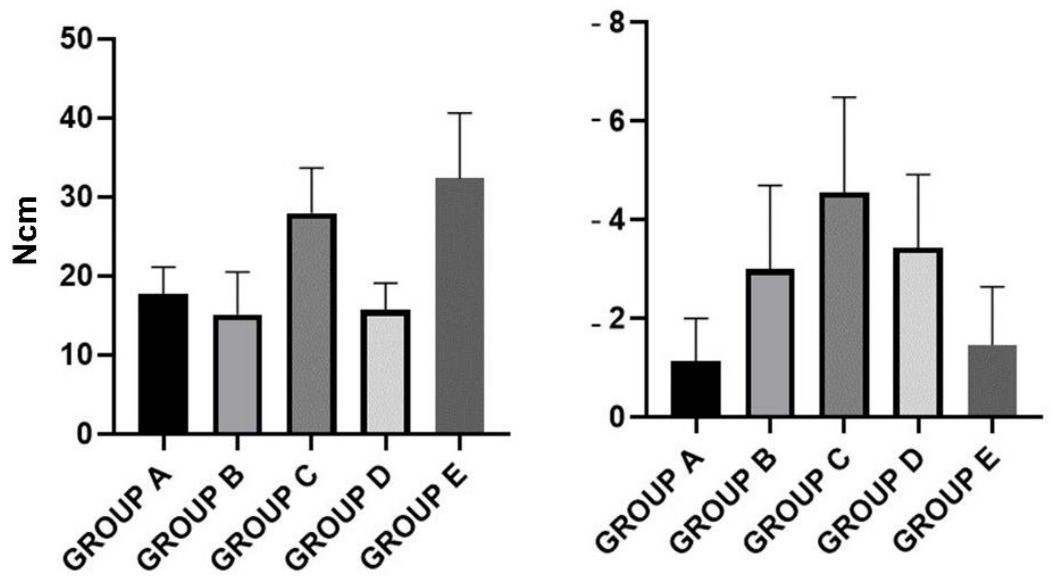

GROUP A

GROUP B

口 GROUPC

口 GROUPD

Figure 8. Insertion torque and Periotest means of the study groups. 
Table 2. Insertion torque comparison between the study groups (ANOVA, Sidak post hoc test).

\begin{tabular}{cccc}
\hline Insertion Torque & Mean Difference & $\mathbf{9 5 . 0 0 \% ~ C I ~}$ & $p$-Value \\
\hline GROUP A vs. GROUP B & 2.600 & -2.414 to 7.614 & 0.7801 \\
\hline GROUP A vs. GROUP C & -10.20 & -15.21 to -5.186 & $<0.0001$ \\
\hline GROUP A vs. GROUP D & 2.050 & -2.964 to 7.064 & 0.9392 \\
\hline GROUP A vs. GROUP E & -14.55 & -19.56 to -9.536 & $<0.0001$ \\
\hline GROUP B vs. GROUP C & -12.80 & -17.81 to -7.786 & $<0.0001$ \\
\hline GROUP B vs. GROUP D & -0.5500 & -5.564 to 4.464 & $>0.9999$ \\
\hline GROUP B vs. GROUP E & -17.15 & -22.16 to -12.14 & $<0.0001$ \\
\hline GROUP C vs. GROUP D & 12.25 & 7.236 to 17.26 & $<0.0001$ \\
\hline GROUP C vs. GROUP E & -4.350 & -9.364 to 0.6643 & 0.1372 \\
\hline
\end{tabular}

Table 3. Periotest means of the study groups.

\begin{tabular}{ccc}
\hline Periotest & Mean & SD \\
\hline GROUP A & -1.143 & 0.8603 \\
\hline GROUP B & -2.998 & 1.703 \\
\hline GROUP C & -4.563 & 1.93 \\
\hline GROUP D & -3.438 & 1.486 \\
\hline GROUP E & -1.463 & 1.183 \\
\hline
\end{tabular}

Table 4. Periotest comparison between the study groups (ANOVA, Sidak post hoc test).

\begin{tabular}{cccc}
\hline Periotest & Mean Difference & $\mathbf{9 5 . 0 0 \% ~ C I ~}$ & $p$-Value \\
\hline GROUP A vs. GROUP B & 1.855 & 3.158 to 0.5523 & 0.0013 \\
\hline GROUP A vs. GROUP C & 3.420 & 4.723 to 2.117 & $<0.0001$ \\
\hline GROUP A vs. GROUP D & 2.295 & 3.598 to 0.9923 & $<0.0001$ \\
\hline GROUP A vs. GROUP E & 0.3200 & 1.623 to -0.9827 & 0.9597 \\
\hline GROUP B vs. GROUP C & 1.565 & 2.868 to -0.2623 & 0.0103 \\
\hline GROUP B vs. GROUP D & 0.4400 & 1.743 to -0.8627 & 0.8808 \\
\hline GROUP B vs. GROUP E & -1.535 & -0.2323 to -2.838 & 0.0125 \\
\hline GROUP C vs. GROUP D & -1.125 & 0.1777 to -2.428 & 0.1239 \\
\hline GROUP C vs. GROUP E & -3.100 & -1.797 to -4.403 & $<0.0001$ \\
\hline
\end{tabular}

\section{Discussion}

Alveolar bone density could vary significantly between maxilla and mandible. Quantitative data provided evidence that maxillary anterior areas are significantly denser than posterior ones. In maxilla, the highest bone density was observed in the canine and premolar areas, with no differences about the amount of cancellous bone present [42]. On the other hand, cortical bone increased in thickness from anterior to posterior maxilla [43].

Primary stability may be difficult to achieve in low bone density regions. Primary stability is a prerequisite for osteointegration resulting from the mechanical interaction between bone tissue and the implant immediately after placement [44-46]. Implant micromovement below the 50-150 $\mu \mathrm{m}$ threshold promotes proliferation and differentiation of the osteoblast cells and inhibits fibrous tissue invasion and encapsulation [44]. Moreover, also the osteotomy preparation technique represents a key factor to achieve implant primary stability. In fact, the undersize preparation drilling represent one of the most widespread protocol for very low-density bone (D4-D5) [47]. The disadvantage of this technique is 
quite operator dependent and clinically not reproducible, while other techniques such as osteocondensation and ultrasonic preparation are standardized approaches [47]. Stacchi et al. reported in vivo a significant difference of the stability ultrasonic device group after 90 days of implant healing compared to the standard drilling protocol [48]. Moreover, a significant increase in the operative time was associated to the ultrasonic preparation protocol [48]. In another study, Scarano et al. reported no significant difference of crestal resorption between the two techniques after the implant osseointegration process with a significant decrease in the clinical pain and symptoms associated to the ultrasonic technique [22].

In the present investigation, different diameters and implant macrogeometries were tested on polyurethane bone blocks. Moreover, the comparation of the micromovement between one-stage and two-stage implants could represent a weak point for Periotest measurement. In fact, this aspect could introduce an increased risk of measurement bias and a sensible increase in the Periotest value for one-stage implant that could represent a potential limit of the present investigation.

According to the rationale of the present study, also the identification of the more appropriate implant fixture diameter is effective to obtain an higher implant primary stability in low-density regions due to residual thickness of the alveolar ridge [9].

The others clinical factors that affect primary stability were bone quantity and quality [49-51], surgical technique [52], surface treatment [32,53-56], microtopography [57,58], and implant macro-geometry (shape, length, diameter, and thread design) [53,59,60].

In the present study, the higher stability on 20 PCF polyurethane was obtained with a $1.2 \mathrm{~mm}$ thread pitch, $32^{\circ}$ helix angle, and a round apex implant, while the other geometries showed insertion torque values of less than $20 \mathrm{Ncm}^{2}$. The choice of the optimal implant geometry for the local anatomy and bone density represents a priority in the daily clinical practice. The presence or absence of threads, additional macro-irregularities, and the shape/outline of the implant are considered some of the most significant aspects for a successful implant primary stability. Thread shape (e.g., square, V-shaped, and buttress) affects the direction of load from the prosthesis to bone. Moreover, the presence of surface irregularities represent an important characteristic of the implant textures that is generally associated to a macrogeometry with larger threads profiles and internal angles [61,62]. These aspects are histologically and clinically associated to an increase in the mechanical friction between the implant irregularities and the surrounding bone and an higher longterm stability of the fixture $[61,62]$.

This reduces the development of shear at the dental implant-tissue interface so as to improve long-term success $[37,63,64]$. In the same way, implant design is important especially in cases of poor bone quality and immediate post-extractive implant. According to Ao and colleagues, the optimal thread width and depth for the immediately loaded cylinder implants were $0.18-0.3 \mathrm{~mm}$ and $0.35-0.5 \mathrm{~mm}$, respectively. In addition, the stress concentration of the bone in the direction of depth was found to be a more sensitive factor in respect to the direction of width [65]. It has been suggested that smaller pitch presented better load resistance and lesser effective stress in three-dimensional FEA models, but the optimal pitch values could be found in different thread shapes [66]. A thread pitch of $0.8 \mathrm{~mm}$ was found to be optimal for achieving primary stability and optimum stress production on cylindrical implants with V-shaped threads [67]. Several studies suggested that insertion torque values in the range of $25-45 \mathrm{Ncm}$ were desirable for improved implant integration. The IT is fundamental also for evaluating the possibility of immediate loading protocols: Calandriello et al. in 2003 indicated a minimum IT of $60 \mathrm{Ncm}$ for single teeth, $45 \mathrm{Ncm}$ for implants supporting partial-arch restorations, and $32 \mathrm{Ncm}$ for implants supporting full-arch restorations [68]. However, Del Giudice et al. in a retrospective study, published in 2019, suggested that these values could be lowered, thanks to the technological improvements of implant surfaces and the surgical tools and the refinements of the surgical protocols, according to the recent literature [69]. 
However, the correlation between high IT and high implant primary stability may not hold true for all implant designs and associated surgical drilling techniques [70].

\section{Conclusions}

According to the effectiveness of the present study, implants with wider V-thread pitch and a round apex showed a higher primary stability in a simulated D2 model, and their use could be suggested in bone regions such as the anterior lower jaw.

Author Contributions: Conceptualization, A.P., S.F., and G.I.; methodology, A.P. and S.F.; software, M.T., M.P., and P.P.; validation, A.P., S.F., and G.I.; formal analysis, P.P. and M.T.; investigation, A.P., S.F., M.T., and P.P.; data curation, M.T. and P.P.; writing—original draft preparation, A.P. and M.T.; writing - review and editing, M.T. and A.P.; visualization, A.P., S.F., and G.I.; supervision, A.P., G.I., and S.F. All authors have read and agreed to the published version of the manuscript.

Funding: This research received no external funding.

Data Availability Statement: The study data are available under request to the corresponding author.

Acknowledgments: The authors declare no acknowledgement for the present research.

Conflicts of Interest: The authors declare no conflict of interests for the present research.

\section{References}

1. Albrektsson, T.; Lekholm, U. Osseointegration: Current state of the art. Dent. Clin. North Am. 1989, 33, 537-554.

2. Abuhussein, H.; Pagni, G.; Rebaudi, A.; Wang, H.-L. The effect of thread pattern upon implant osseointegration. Clin. Oral. Implant. Res. 2010, 21, 129-136. [CrossRef]

3. Branemark, P.-I. Osseointegration and its experimental background. J. Prosthet. Dent. 1983, 50, 399-410. [CrossRef]

4. Parithimarkalaignan, S.; Padmanabhan, T.V. Osseointegration: An Update. J. Indian Prosthodont. Soc. 2013, 13, 2-6. [CrossRef]

5. Gehrke, A.; Mazon, P.; Del Fabbro, M.; Tumedei, M.; Aramburù, J.; Perez-Diaz, L.; De Aza, P. Histological and His-tomorphometric Analyses of Two Bovine Bone Blocks Implanted in Rabbit Calvaria. Symmetry 2019, 11, 641. [CrossRef]

6. Tumedei, M.; Savadori, P.; Del Fabbro, M.; Fabbro, D. Synthetic Blocks for Bone Regeneration: A Systematic Review and Meta-Analysis. Int. J. Mol. Sci. 2019, 20, 4221. [CrossRef]

7. Gao, S.-S.; Zhang, Y.-R.; Zhu, Z.-L.; Yu, H.-Y. Micromotions and combined damages at the dental implant/bone interface. Int. J. Oral. Sci. 2012, 4, 182-188. [CrossRef]

8. Piattelli, A.; Scarano, A.; Piattelli, M. Microscopical aspects of failure in osseointegrated dental implants: A report of five cases. Biomaterials 1996, 17, 1235-1241. [CrossRef]

9. Olate, S.; Lyrio, M.C.N.; De Moraes, M.; Mazzonetto, R.; Moreira, R.W.F. Influence of Diameter and Length of Implant on Early Dental Implant Failure. J. Oral. Maxillofac. Surg. 2010, 68, 414-419. [CrossRef] [PubMed]

10. Gehrke, S.A.; Tumedei, M.; Júnior, J.A.; Treichel, T.L.E.; Kolerman, R.; Lepore, S.; Piattelli, A.; Iezzi, G. Histological and Histomorphometrical Evaluation of a New Implant Macrogeometry. A Sheep Study. Int. J. Environ. Res. Public Health 2020, 17, 3477. [CrossRef] [PubMed]

11. Kuroshima, S.; Yasutake, M.; Tsuiki, K.; Nakano, T.; Sawase, T. Structural and Qualitative Bone Remodeling Around Repetitive Loaded Implants in Rabbits. Clin. Implant. Dent. Relat. Res. 2015, 17, e699-e710. [CrossRef] [PubMed]

12. Davies, J.E. Understanding Peri-Implant Endosseous Healing. J. Dent. Educ. 2003, 67, 932-949. [CrossRef]

13. Albrektsson, T.; Eriksson, A.; Friberg, B.; Lekholm, U.; Lindahl, L.; Nevins, M.; Oikarinen, V.; Roos, J.; Sennerby, L.; Astrand, P. Histologic investigations on 33 retrieved Nobelpharma implants. Clin. Mater. 1993, 12, 1-9. [CrossRef]

14. Amari, Y.; Piattelli, A.; Alccayhuaman, K.A.A.; Mesa, N.F.; Ferri, M.; Iezzi, G.; Botticelli, D. Bone healing at non-submerged implants installed with different insertion torques: A split-mouth histomorphometric randomized controlled trial. Int. J. Implant. Dent. 2019, 5, 1-9. [CrossRef] [PubMed]

15. Fujiwara, S.; Kato, S.; Bengazi, F.; Velez, J.U.; Tumedei, M.; Kotsu, M.; Botticelli, D. Healing at implants installed in osteotomies prepared either with a piezoelectric device or drills: An experimental study in dogs. Oral. Maxillofac. Surg. 2021, 25, 65-73. [CrossRef]

16. Kotsu, M.; Velez, J.U.; Bengazi, F.; Tumedei, M.; Fujiwara, S.; Kato, S.; Botticelli, D. Healing at implants installed from $~ 70$ - to < 10-Ncm insertion torques: An experimental study in dogs. Oral. Maxillofac. Surg. 2021, 25, 55-64. [CrossRef]

17. Huwais, S.; Meyer, E.G. A Novel Osseous Densification Approach in Implant Osteotomy Preparation to Increase Biomechanical Primary Stability, Bone Mineral Density, and Bone-to-Implant Contact. Int. J. Oral. Maxillofac. Implant. 2017, 32, 27-36. [CrossRef]

18. Kuroshima, S.; Kaku, M.; Ishimoto, T.; Sasaki, M.; Nakano, T.; Sawase, T. A paradigm shift for bone quality in dentistry: A literature review. J. Prosthodont. Res. 2017, 61, 353-362. [CrossRef]

19. Degidi, M.; Daprile, G.; Piattelli, A. Influence of Underpreparation on Primary Stability of Implants Inserted in Poor Quality Bone Sites: An In Vitro Study. J. Oral. Maxillofac. Surg. 2015, 73, 1084-1088. [CrossRef] [PubMed] 
20. Misch, C.E.; Judy, K.W. Classification of partially edentulous arches for implant dentistry. Int. J. Oral. Implant. Implant. 1987, 4, 7-13.

21. Misch, C.E. Bone Density: A Key Determinant for Clinical Success. Contemp. Implant. Dent. 1999, 8, $109-118$.

22. Scarano, A.; Carinci, F.; Lorusso, F.; Festa, F.; Bevilacqua, L.; De Oliveira, P.S.; Maglione, M. Ultrasonic vs Drill Implant Site Preparation: Post-Operative Pain Measurement Through VAS, Swelling and Crestal Bone Remodeling: A Randomized Clinical Study. Materials 2018, 11, 2516. [CrossRef] [PubMed]

23. Favero, V.; Sakuma, S.; Alccayhuaman, K.A.A.; Benedetto, G.A.; Bengazi, F.; Botticelli, D. Healing at sites prepared using different drilling protocols. An experimental study in the tibiae of sheep. PLoS ONE 2018, 13, e0202957. [CrossRef] [PubMed]

24. Trisi, P.; Berardini, M.; Falco, A.; Vulpiani, M.P. New Osseodensification Implant Site Preparation Method to Increase Bone Density in Low-Density Bone. Implant. Dent. 2016, 25, 24-31. [CrossRef] [PubMed]

25. Lahens, B.; Neiva, R.; Tovar, N.; Alifarag, A.M.; Jimbo, R.; Bonfante, E.A.; Bowers, M.M.; Cuppini, M.; Freitas, H.; Witek, L.; et al. Biomechanical and histologic basis of osseodensification drilling for endosteal implant placement in low density bone. An experimental study in sheep. J. Mech. Behav. Biomed. Mater. 2016, 63, 56-65. [CrossRef]

26. Zizzari, V.L.; Berardi, D.; Congedi, F.; Tumedei, M.; Cataldi, A.; Perfetti, G. Morphological Aspect and iNOS and Bax Expression Modification in Bone Tissue Around Dental Implants Positioned Using Piezoelectric Bone Surgery Versus Conventional Drill Technique. J. Craniofacial Surg. 2015, 26, 741-744. [CrossRef]

27. Scarano, A.; Inchingolo, F.; Murmura, G.; Traini, T.; Piattelli, A.; Lorusso, F. Three-Dimensional Architecture and Mechanical Properties of Bovine Bone Mixed with Autologous Platelet Liquid, Blood, or Physiological Water: An In Vitro Study. Int. J. Mol. Sci. 2018, 19, 1230. [CrossRef]

28. Scarano, A.; Noumbissi, S.; Gupta, S.; Inchingolo, F.; Stilla, P.; Lorusso, F. Scanning Electron Microscopy Analysis and Energy Dispersion X-ray Microanalysis to Evaluate the Effects of Decontamination Chemicals and Heat Sterilization on Implant Surgical Drills: Zirconia vs. Steel. Appl. Sci. 2019, 9, 2837. [CrossRef]

29. Degidi, M.; Daprile, G.; Piattelli, A. Primary Stability Determination by Means of Insertion Torque and RFA in a Sample of 4,135 Implants. Clin. Implant. Dent. Relat. Res. 2010, 14, 501-507. [CrossRef]

30. Valente, M.L.D.C.; De Castro, D.T.; Shimano, A.C.; Lepri, C.P.; Dos Reis, A.C. Analysis of the influence of implant shape on primary stability using the correlation of multiple methods. Clin. Oral. Investig. 2015, 19, 1861-1866. [CrossRef]

31. Allen, R.F.; Baldini, N.C.; Donofrio, P.E.; Gutman, E.L.; Keefe, E.; Kramer, J.G. Standard Specification for Rigid Poly-urethane Foam for Use as a Standard Material for Testing Orthopedic Devices and Instruments (F1839-97). In Annual Book of ASTM Standards, Medical Devices and Services; ASTM: West Conshohocken, PA, USA, 1998.

32. Cordioli, G.; Majzoub, Z.; Piattelli, A.; Scarano, A. Removal Torque and Histomorphometric Investigation of 4 Dif-ferent Titanium Surfaces: An Experimental Study in the Rabbit Tibia. Int. J. Oral. Maxillofac. Implants 2000, 15, 668-674. [PubMed]

33. Di Stefano, D.A.; Arosio, P.; Perrotti, V.; Iezzi, G.; Scarano, A.; Piattelli, A. Correlation between Implant Geometry, Bone Density, and the Insertion Torque/Depth Integral: A Study on Bovine Ribs. Dent. J. 2019, 7, 25. [CrossRef] [PubMed]

34. Abbott, J.R.; Marino, V.; Bartold, P.M. Human cadaveric histomorphological and metallurgical analysis of dental implants following 12.5 years of service. Clin. Oral. Implant. Res. 2012, 25, 266-271. [CrossRef]

35. Comuzzi, L.; Iezzi, G.; Piattelli, A.; Tumedei, M. An In Vitro Evaluation, on Polyurethane Foam Sheets, of the Insertion Torque (IT) Values, Pull-Out Torque Values, and Resonance Frequency Analysis (RFA) of NanoShort Dental Implants. Polymer 2019, 11, 1020. [CrossRef]

36. Comuzzi, L.; Tumedei, M.; Pontes, A.E.; Piattelli, A.; Iezzi, G. Primary Stability of Dental Implants in Low-Density (10 and 20 pcf) Polyurethane Foam Blocks: Conical vs Cylindrical Implants. Int. J. Environ. Res. Public Health 2020, 17, 2617. [CrossRef]

37. Comuzzi, L.; Tumedei, M.; Piattelli, A.; Iezzi, G. Short vs. Standard Length Cone Morse Connection Implants: An In Vitro Pilot Study in Low Density Polyurethane Foam. Symmetry 2019, 11, 1349. [CrossRef]

38. Tumedei, M.; Piattelli, A.; Degidi, M.; Mangano, C.; Iezzi, G. A Narrative Review of the Histological and Histomorphometrical Evaluation of the Peri-Implant Bone in Loaded and Unloaded Dental Implants. A 30-Year Experience (1988-2018). Int. J. Environ. Res. Public Health 2020, 17, 2088. [CrossRef] [PubMed]

39. Tumedei, M.; Piattelli, A.; Degidi, M.; Mangano, C.; Iezzi, G. A 30-Year (1988-2018) Retrospective Microscopical Evaluation of Dental Implants Retrieved for Different Causes: A Narrative Review. Int. J. Periodontics Restor. Dent. 2020, 40, e211-e227. [CrossRef] [PubMed]

40. ASTM. F 67-95: Standard Specification for Unalloyed Titanium for Surgical Implant Applications. In Annual Book of ASTM Standards; ASTM: Philadelphia, PA, USA, 1995.

41. Devlin, H.; Horner, K.; Ledgerton, D. A comparison of maxillary and mandibular bone mineral densities. J. Prosthet. Dent. 1998, 79, 323-327. [CrossRef]

42. Di Stefano, D.A.; Arosio, P.; Pagnutti, S.; Vinci, R.; Gherlone, E.F. Distribution of Trabecular Bone Density in the Maxilla and Mandible. Implant. Dent. 2019, 28, 340-348. [CrossRef]

43. Katranji, A.; Misch, K.; Wang, H.-L. Cortical Bone Thickness in Dentate and Edentulous Human Cadavers. J. Periodontol. 2007, 78, 874-878. [CrossRef] [PubMed]

44. Anitua, E.; Alkhraisat, M.H.; Piñas, L.; Orive, G. Efficacy of biologically guided implant site preparation to obtain adequate primary implant stability. Ann. Anat.-Anat. Anz. 2015, 199, 9-15. [CrossRef] [PubMed] 
45. Scarano, A.; De Oliveira, P.S.; Traini, T.; Lorusso, F. Sinus Membrane Elevation with Heterologous Cortical Lamina: A Randomized Study of a New Surgical Technique for Maxillary Sinus Floor Augmentation without Bone Graft. Materials 2018, $11,1457$. [CrossRef] [PubMed]

46. Di Stefano, D.A.; Arosio, P.; Gastaldi, G.; Gherlone, E. The insertion torque-depth curve integral as a measure of implant primary stability: An in vitro study on polyurethane foam blocks. J. Prosthet. Dent. 2018, 120, 706-714. [CrossRef] [PubMed]

47. Anitua, E.; Murias-Freijo, A.; Alkhraisat, M.H. Implant Site Under-Preparation to Compensate the Remodeling of an Autologous Bone Block Graft. J. Craniofacial Surg. 2015, 26, e374-e377. [CrossRef] [PubMed]

48. Stacchi, C.; Vercellotti, T.; Torelli, L.; Furlan, F.; Di Lenarda, R. Changes in Implant Stability Using Different Site Preparation Techniques: Twist Drills versus Piezosurgery. A Single-Blinded, Randomized, Controlled Clinical Trial. Clin. Implant. Dent. Relat. Res. 2011, 15, 188-197. [CrossRef] [PubMed]

49. Fu, M.-W.; Fu, E.; Lin, F.-G.; Chang, W.-J.; Hsieh, Y.-D.; Shen, E.-C. Correlation Between Resonance Frequency Analysis and Bone Quality Assessments at Dental Implant Recipient Sites. Int. J. Oral. Maxillofac. Implant. 2017, 32, 180-187. [CrossRef]

50. Andruch, K.; Płachta, A. Evaluating Maxilla Bone Quality Through Clinical Investigation of Voxel Grey Scale Values from Cone-Beam Computed Tomography for Dental Use. Adv. Clin. Exp. Med. 2015, 24, 1071-1077. [CrossRef]

51. Romanos, G.E.; Delgado-Ruiz, R.A.; Sacks, D.; Calvo-Guirado, J.L. Influence of the implant diameter and bone quality on the primary stability of porous tantalum trabecular metal dental implants: Anin vitrobiomechanical study. Clin. Oral. Implant. Res. 2016, 29, 649-655. [CrossRef]

52. Degidi, M.; Daprile, G.; Piattelli, A. Influence of Stepped Osteotomy on Primary Stability of Implants Inserted in Low-Density Bone Sites: An In Vitro Study. Int. J. Oral. Maxillofac. Implant. 2017, 32, 37-41. [CrossRef]

53. Scarano, A.; Crocetta, E.; Quaranta, A.; Lorusso, F. Influence of the Thermal Treatment to Address a Better Osseointegration of Ti6Al4V Dental Implants: Histological and Histomorphometrical Study in a Rabbit Model. BioMed. Res. Int. 2018, 2018, 1-7. [CrossRef]

54. Buser, D.; Schenk, R.K.; Steinemann, S.; Fiorellini, J.P.; Fox, C.H.; Stich, H. Influence of surface characteristics on bone integration of titanium implants. A histomorphometric study in miniature pigs. J. Biomed. Mater. Res. 1991, 25, 889-902. [CrossRef]

55. Scarano, A.; Assenza, B.; Inchingolo, F.; Mastrangelo, F.; Lorusso, F. New Implant Design with Midcrestal and Apical Wing Thread for Increased Implant Stability in Single Postextraction Maxillary Implant. Case Rep. Dent. 2019, 2019, 1-4. [CrossRef] [PubMed]

56. Maglione, M.; Bevilacqua, L.; Dotto, F.; Costantinides, F.; Lorusso, F.; Scarano, A. Observational Study on the Preparation of the Implant Site with Piezosurgery vs. Drill: Comparison between the Two Methods in terms of Postoperative Pain, Surgical Times, and Operational Advantages. BioMed. Res. Int. 2019, 2019, 1-6. [CrossRef] [PubMed]

57. Mangano, C.; Shibli, J.A.; Pires, J.T.; Luongo, G.; Piattelli, A.; Iezzi, G. Early Bone Formation around Immediately Loaded Transitional Implants Inserted in the Human Posterior Maxilla: The Effects of Fixture Design and Surface. BioMed. Res. Int. 2017, 2017, 1-8. [CrossRef]

58. Mangano, F.G.; Pires, J.T.; Shibli, J.A.; Mijiritsky, E.; Iezzi, G.; Piattelli, A.; Mangano, C. Early Bone Response to Dual Acid-Etched and Machined Dental Implants Placed in the Posterior Maxilla. Implant. Dent. 2017, 26, 24-29. [CrossRef] [PubMed]

59. Steigenga, J.T.; Al-Shammari, K.F.; Nociti, F.H.; Misch, C.E.; Wang, H.-L. Dental Implant Design and Its Relationship to Long-Term Implant Success. Implant. Dent. 2003, 12, 306-317. [CrossRef] [PubMed]

60. Toyoshima, T.; Tanaka, H.; Ayukawa, Y.; Howashi, M.; Masuzaki, T.; Kiyosue, T.; Koyano, K.; Nakamura, S. Primary Stability of a Hybrid Implant Compared with Tapered and Cylindrical Implants in an Ex Vivo Model. Clin. Implant. Dent. Relat. Res. 2014, 17, 950-956. [CrossRef]

61. Naves, M.M.; Menezes, H.H.M.; Magalhães, D.; Ferreira, J.A.; Ribeiro, S.F.; De Mello, J.D.B.; Costa, H.L. Effect of Macrogeometry on the Surface Topography of Dental Implants. Int. J. Oral. Maxillofac. Implant. 2015, 30, 789-799. [CrossRef] [PubMed]

62. Yeo, I.-S.L. Modifications of Dental Implant Surfaces at the Micro- and Nano-Level for Enhanced Osseointegration. Materials 2019, 13, 89. [CrossRef]

63. Bumgardner, J.D.; Boring, G.J.; Cooper, R.C.; Gao, C.; Givaruangsawat, S.; Gilbert, J.A.; Misch, C.M.; Steflik, D.E. Preliminary Evaluation of a New Dental Implant Design in Canine Models. Implant. Dent. 2000, 9, 252-260. [CrossRef]

64. Fanali, S.; Tumedei, M.; Pignatelli, P.; Inchingolo, F.; Pennacchietti, P.; Pace, G.; Piattelli, A. Implant primary stability with an osteocondensation drilling protocol in different density polyurethane blocks. Comput. Methods Biomech. Biomed. Eng. 2020, 1-7. [CrossRef] [PubMed]

65. Ao, J.; Li, T.; Liu, Y.; Ding, Y.; Wu, G.; Hu, K.; Kong, L. Optimal design of thread height and width on an immediately loaded cylinder implant: A finite element analysis. Comput. Biol. Med. 2010, 40, 681-686. [CrossRef] [PubMed]

66. Chun, H.-J.; Cheong, S.-Y.; Han, J.-H.; Heo, S.-J.; Chung, J.-P.; Rhyu, I.-C.; Choi, Y.-C.; Baik, H.-K.; Ku, Y.; Kim, M.-H. Evaluation of design parameters of osseointegrated dental implants using finite element analysis. J. Oral. Rehabil. 2002, 29, 565-574. [CrossRef] [PubMed]

67. Kong, L.; Liu, B.; Hu, K.-J.; Li, D.-H.; Song, Y.-L.; Ma, P.; Yang, J. [Optimized thread pitch design and stress analysis of the cylinder screwed dental implant]. Hua Xi Kou Qiang Yi Xue Za Zhi 2006, 24, 509-512. [PubMed]

68. Calandriello, R.; Tomatis, M.; Rangert, B. Immediate functional loading of Brånemark System implants with enhanced initial stability: A prospective 1- to 2-year clinical and radiographic study. Clin. Implant. Dent. Relat. Res. 2003, 5, 10-20. [CrossRef] [PubMed] 
69. Del Giudice, R.; Piattelli, A.; Grande, N.-M.; Cataneo, E.; Crispino, A.; Petrini, M. Implant insertion torque value in immediate loading: A retrospective study. Med. Oral. Patol. Oral. Cir. Bucal 2019, 24, e398-e403. [CrossRef] [PubMed]

70. Akkocaoglu, M.; Uysal, S.; Tekdemir, I.; Akca, K.; Cehreli, M.C. Implant design and intraosseous stability of immediately placed implants: A human cadaver study. Clin. Oral. Implant. Res. 2005, 16, 202-209. [CrossRef] 